\title{
A STUDY INTO THE AWARENESS AND ACCEPTANCE OF UTILIZING VINE BRANCHES IN THE MICRO-REGION OF GYÖNGYÖS
}

\author{
Cecília Gonda
}

Institute of Agroinformatics and Rural Development, Károly Róbert University College

\begin{abstract}
Apstract: Every year, a significant amount of renewable dendromass is generated in Hungary. Various possibilities have been recognised by today that are not widespread yet. The greatest obstacle is frequently derived from the lack of the farmers' knowledge as without having the required knowledge obtained they can become distrustful or adequate efficiency will not be achieved during utilisation.

In order to improve the rate of utilisation, targeted information methodologies should be applied that comply with the farmers' knowledge. In this present study, the awareness and acceptance of vine-growers from the Micro-region of Gyöngyös related to the use of vine branches will be analysed based on the results of a questionnaire survey.

The survey was conducted in accordance with the number of wine-community members in personal interviews. The questionnaire contained questions about the farm, the use of vine branches as well as about the farmers.

Based on the results, information was obtained on the reasons for the use of by-products not being wide-spread among farmers as well as on the sources of information obtained. For the fragmented farms which are typical here it is important to know whether by-products are not utilised as it is not how they can be used or whether the vineyard is cultivated by others therefore the farmer lacks machinery. The level of acceptance was also studied by asking a question on the possible offer of the by-products for greater-scale site.

Our intention is to assist the generally badly off farmers to use the annually generated by-products in a reasonable way. This can be realized by various ways of providing information. By applying the results of the survey, adequate methods and knowledge can be provided for farmers.
\end{abstract}

Key words: renewable energy sources, vineyards, use of by-products, questionnaire survey

\section{Introduction}

It is extremely disadvantageous for Hungary from both energy security and climate protection considerations that more than $77 \%$ of the fossil energy demand is covered by imported energy sources. The renewable energy production is very low, representing only $4.1 \%$ within the full energy consumption in 2005 and this figure was mostly achieved in an environmentally unsustainable manner (NÉS 2005). In the meantime, a significant amount of renewable energy, especially dendromass, can be obtained as a by-product from agricultural activities the present utilisation of which is not significant either and for most procedures it is limited to some reference plants only. The further higher scale of utilisation requires having ecological, technical and economic preconditions established (Kacz and Neményi 1998). However, the simple energy consuming nature of agriculture cannot be accepted. Therefore, an energy-producing agriculture should be established opening a new era in energy production (FVM 1999).

Energy supply based on local resources and structures results in energy security and lower exposedness. The use of by-products generated can facilitate a decrease of costs or even a small increase of incomes for those making their living from this sector as well as cut down the lack of capital for other potential biomass suppliers e.g. municipalities (Pintér et al. 2009).

In the country's different regions, with various physical and economic endowments, various crops are grown at a larger scale. After having them surveyed, the potential methods of utilisation should be specified as well as acceptance levels among farmers should be acquired.

\section{Methods}

Vine-growing is a characteristic agricultural activity in the Micro-region of Gyöngyös located at the southern foothills of the Mátra Mountains in which one of the highest rate of wasting energy is observed when the resultant vine branches are eliminated unutilised after grape pruning. Some initial efforts can already be witnessed for its utilisation which cannot be regarded as wide-spread. To achieve this, a new methodology should be elaborated prior to which, as a first step, knowledge about vine-growers, the endowments and the machinery fleet supply of their vineyards should be acquired. 
Such information along with the level of the awareness about and the acceptance of the various methods of utilisation were gained by conducting a questionnaire survey (Baros 2004; Patkós and Baros 2004).

200 questionnaires were completed in accordance with the number of wine community members in the Mátra wine region. The questionnaire contained questions in three topics: the farm, the use of vine branches and the personal data of the farmers.

The questionnaire's most specific section is the analysis carried out about the use of vine branches, therefore it was further segmented. Vine-growers are expected to neglect utilisation for three reasons. In case of having inadequate information it is possible that they have not been informed about either this possibility or about its implementation yet. Another possibility is that farmers draw false conclusions from adequate information or they have negative experience. In the meantime, it is not always the vine-growers who cultivate their vineyards, machine cultivation is carried out by suppliers as farmers lack the machinery required.

Carrying out a further analysis of possibilities, it was expedient to study whether their machinery supply is correlated to the size of vine-yards. The methods for analysing the strength of the relationship by applying SPSS were as follows:

- Pearson's Chi-Square Test,

- Sequential Probability Ratio Test,

- Linear Relationship Analysis;

\section{Results}

At present, most of the vine growers in the Micro-region of Gyöngyös $(51.5 \%)$ burn the vine branches at the edge of vineyards heavily polluting the environment. In a similar proportion, vine branches are returned to the soil even if farmers have to assume its extra costs. The number of respondents storing vine branches without elimination as they do not intend to pollute the environment and consider grinding harmful is insignificant $(4.5 \%)$.

Mechanical works in the vineyards are carried out by suppliers in the micro-region (141 respondents), which primarily results from the structure of land being fragmented with vine-growers owning vineyards of the size between 0.1 and 5 hectares in most cases. $28 \%$ of vine-growers own only between $0.3-1$ hectares of land (Figure 1). From the economic point of view, the wide-spreading of new technologies is greatly impeded by this as with such farm sizes the establishment of the machinery required is not possible.

However, the burning up of vine branches is not undertaken by all suppliers thus the task remains for the vine-growers, which results in a vulnerable situation in small-size areas.

Table 1 indicates the results of the analysis into the relationship between vine-growers' available agricultural machinery and the area of vineyards. The value of 26,286 Chi square at 0,000 fault is significant, which means that the relationship is accepted with a fault lower than $0,000 \times 100=0,0 \%$.

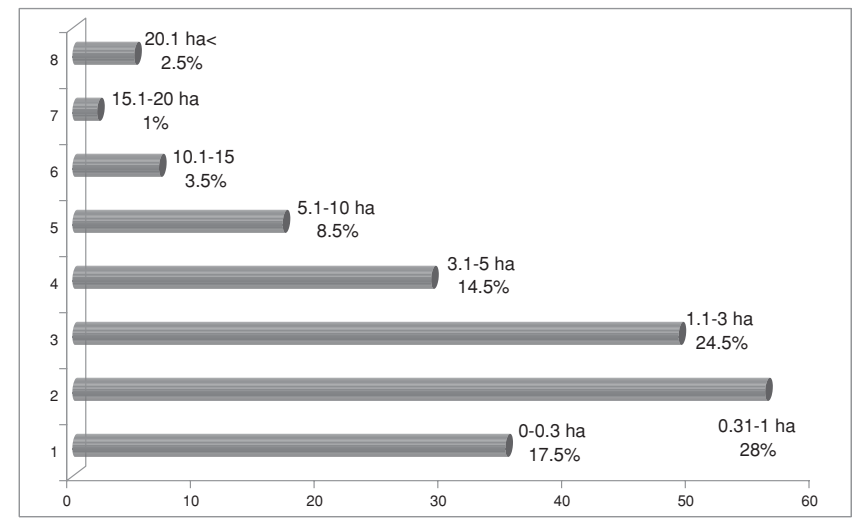

Source: Based on the results of questionnaire survey. $(n=200)$

Figure 1. The size of the respondents' vineyards (\%)

Consequently, the larger the size of the vineyard is, the higher the likelihood of owning agricultural machinery is. This can be explained by the fact according to which for farms with an area exceeding 10 hectares, machinery cost paid to the supplier is so high that it is worth establishing a private machinery fleet, and also the incomes are generated that can cover the costs of purchasing machinery. On the other hand, with the increasing size of farms, time demand is proportionally higher, which means that permanent employment opportunities are created for the farmers.

Table 1. The results of the Pearson's Chi-square test

\begin{tabular}{|l|c|c|c|}
\hline \multicolumn{1}{|c|}{ Categories } & Value & $\begin{array}{c}\text { Diversity } \\
\text { factor }\end{array}$ & $\begin{array}{c}\text { Level } \\
\text { of } \\
\text { significance }\end{array}$ \\
\hline Pearson's Chi-square & 26,28 & 2 &, 000 \\
\hline Probability ratio & 24,898 & 2 &, 000 \\
\hline Linear relationship & 26,084 & 1 &, 000 \\
\hline No. of valid cases (N) & 200 & & \\
\hline
\end{tabular}

Source: Based on the results of the questionnaire survey. $(n=200)$

As indicated by the result on the vine growers' knowledge about the use of vine branches, $96 \%$ of the respondents have heard about some type of utilisation (Figure 2). In most cases, it is related to the heating of homes $(67.5 \%)$. This option was also selected by members from older age groups as they also used to carry vine branches to their homes.

Due to the various sources of information (TV, radio and printed press), $58.5 \%$ of respondents have already heard about vine branches burned in heat power plants whereas $40 \%$ were aware of its use in public institutions. Only $23.5 \%$ was familiar with using it for heating green houses or foil houses. Another way of utilisation, i.e. the heating of a workshop was chosen by one respondents, aiming at such utilisation.

In many cases Respondents, despite not knowing about the possibilities of utilizing vine branches, are informed that it is collected or transformed into some other status (Figure 3). Companies selling cubes arrived at some wine communities and carried out experimental baling for which vine-growers were also invited. This explains why $63.5 \%$ of farmers heard about vine branch balers. Nearly $50 \%$ are aware of chips and 


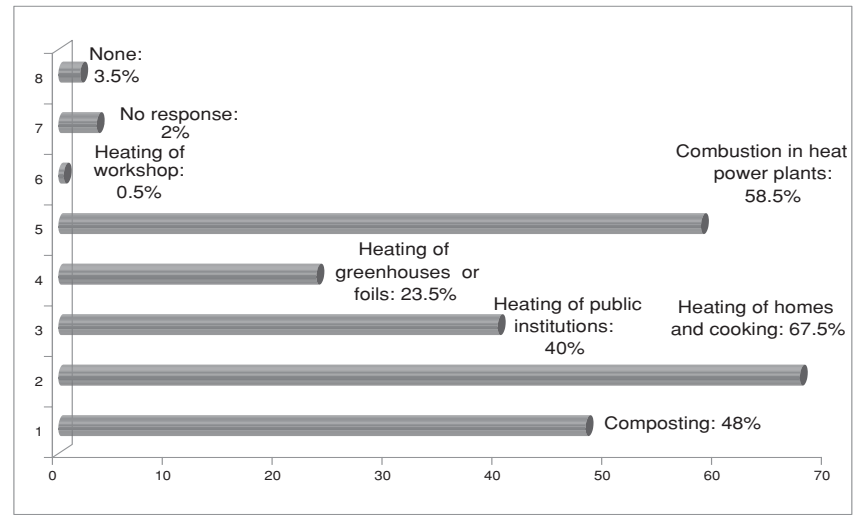

Source: Based on the results of the questionnaire survey. $(n=200)$

Figure 2. The level of knowledge on the methods of utilising vine branches (\%)

briquette production whereas pellet production is somewhat less known $(35 \%)$.

After the responses on the farmers' knowledge were received, questions were asked about their opinion about the use of vine branches. The majority of them associated it with the protection of the environment $(68.5 \%)$ and, in addition to this, it is regarded as cheap energy resource (62.5\%) and assume that it may be an applicable alternative in local energy production $(57 \%)$. According to $45 \%$ of the respondents, this might have a high investment demand and the technology is also judged to be underdeveloped $(39.5 \%)$. They assume that financial support should be provided for such implementations $(43 \%)$. Some of the respondents also indicated that workplaces can be created, however political decisions were not found necessary.

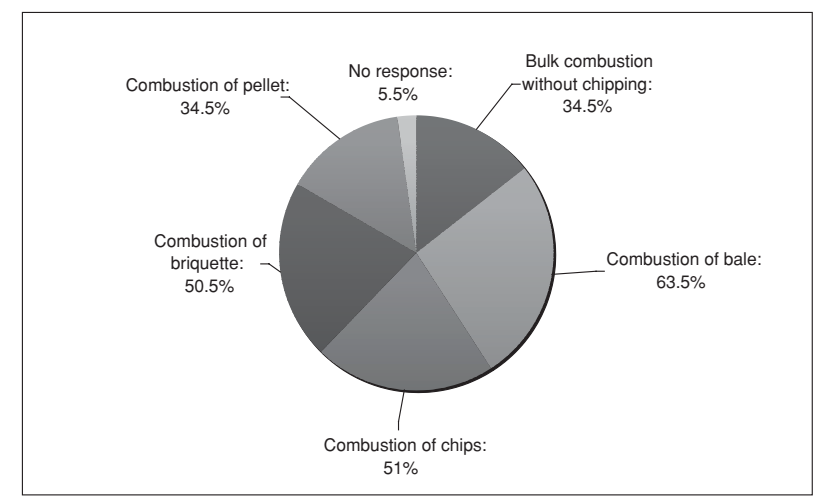

Source: Based on the results of the questionnaire survey. $(n=200)$

Figure 3. The level of awareness of the use of vine branches (\%)

The questionnaire survey ended with an analysis into the level of acceptance of utilizing vine branches. According to this, in case a plant utilizing vine branches was located in the respondents' neighbourhood, $84 \%$ would supply it. Significantly fewer people, $4.5 \%$ indicated the opposite. They are not opposing the idea itself, but they intend to utilize it independently in the future.

Some vine-growers would hand over the vine branches provided no additional cost arose and also consider it important to have the vine branches taken away from the vineyard as soon as possible. Otherwise they will not be able to launch the required springtime field work in time.

\section{Conclusions}

As indicated by the results, vine-growers, despite most of them representing older age groups are generally wellinformed and are open to innovations. However it is also observed that the majority of them own small vineyards frequently not cultivated by themselves. Consequently, it is not worth establishing an own machinery fleet to utilize the vine branches. However, they are open for such utilisation. The arising problems are related to the organisation of tasks and the additional costs of implementation.

In the future, it is expedient to analyse bipolarity regarding the number of vineyards and the sizes of farms from the point of view of logistics. Thus, the steps of implementation should be planned in accordance with such findings.

In case the majority of land is owned by only some farmers, the vine branches generated can be collected by their own machinery fleet and can be transformed into a usable status. Small farmers can easily be convinced through personal discussions.

When lands can be segmented to small parts, tasks should be organised and implemented by suppliers. Such farmers can be informed by posting flyers, using loudspeakers and information evenings, among others.

\section{References}

Kacz, K.., Neményi, M. (1998): Megújuló energiaforrások (Renewable Energy Sources). Mezőgazdasági Szaktudás Kiadó, Budapest, 160. p.

Patkós, Cs., Baros, Z. (2004): A humán erőforrások szerepe a megújuló energiaforrások felhasználásában (The Role of Human Resources in the Use of Renewable Energy Sources). Határon átnyúló kapcsolatok, humán erőforrások című tudományos tanácsülés előadáskötete, Debrecen, 71-75. p.

Baros, Z. (2004): A tűzifa energetikai célú hasznosításának lehetőségei Magyarországon (Possibilities of the Use of Firewood for Energy Purposes in Hungary). A IV. Erdő és Klíma Konferencia előadáskötete, Bakonybél, 263-274. p.

KVM (2007): Nemzeti Éghajlatváltozási Stratégia ((National Climate Change Strategy)) 2008-2025. Környezetvédelmi és Vízügyi Minisztérium, Budapest, 114 p.

FVM (1999): Az agrárgazdaság, a vidékfejlesztés és a területfejlesztés stratégiája (The Strategy of Agriculture, Rural and Regional Development). Földmüvelésügyi és Vidékfejlesztési Minisztérium, Budapest, 1999; 116 p.

Pintér, G., et al. (2009): A szőlővenyige és a fanyesedék biomasszaerőművi beszállításának elemzése (An Analysis of Supplying Biomass Power Plants with Vine branches and Wood-cuttings). Gazdálkodás, 2009 4. szám, 357-363. p. 
